\title{
IMPROVEMENT STRATEGIES OF LIBRARY USAGE AT THE PUBLIC LIBRARIES (A CASE STUDY AT BANTUL PUBLIC LIBRARY YOGYAKARTA)
}

\author{
By Milawati*
}

\begin{abstract}
The role of public libraries in supporting intellectual life of a nation is very strategic as it is to serve all levels of society to acquire and enhance their knowledge. However, in general, the public library condition in Indonesia needs serious improvement because people do not make use of the public libraries. Based on the data, the number of public libraries is not comparable to the existing population in the areas. This fact is in opposite with the condition of the Public Library in Bantul which is heavily used by Bantul community. This study is aimed at finding out the reasons why the Public Library is used by the Society and the strategies used to increase the Public Library usage.This was a case study held in Bantul Public Library. The samples used in this study were the data from Bantul Public Library itself and the Library users who visited and made use of the Library. The data gathering was conducted through direct observation of activities at Bantul Public Library; interviews with the librarians and library users, questionnaires distributed to the Library users, and literature. Data gathered from library research and field studies were analyzed using qualitative descriptive analysis, using SWOT analysis of internal and external environmental factors of the Library that became the basis for formulating the strategy applied in Bantul Public Library. The result shows that strategies applied to improve the Library usage at the Public Libraries in Bantul Yogyakarta are: (a) improving the quality of library human resources, (b) increasing the number of collections based on users' interests and needs, (c) creating comfortable library condition, (d) providing the best services to the community (e) building partnership to cope with limited facilities, infrastructures and budgets of local government; $(f)$ increasing public understanding on the existence and benefits of the Library through library promotion regularly.
\end{abstract}

Keywords : Public library, library usage, Public library strategy

* Mahasiswa MIP UGM

\section{A. PENDAHULUAN}

Perpustakaan sebagaimana yang ada dan berkembang sekarang dipergunakan sebagai salah satu pusat informasi, sumber ilmu pengetahuan, penelitian, rekreasi, pelestarian khasanah budaya bangsa serta berbagai jasa lainnya. Dalam Keputusan Presiden No. 11 tahun 1989 ditegaskan bahwa "perpustakaan merupakan salah satu sarana pelestarian bahan pustaka sebagai hasil budaya dan mempunyai fungsi sebagai sumber informasi ilmu pengetahuan, teknologi, dan kebudayaan dalam rangka mencerdaskan kehidupan bangsa dan menunjang pelaksanaan pembangunan nasional". Peran dan tujuan dari perpustakaan adalah sebagai wahana untuk mencerdaskan bangsa supaya tercapai masyarakat yang terdidik. Keberadaan perpustakaan dapat diartikan juga sebagai pemenuhan kebutuhan yang diakui masyarakat, kebutuhan ini menentukan bentuk, tujuan, fungsi, program dan jasa perpustakaan serta sebagai penunjang utama masyarakat yang beradab.

Perpustakaan umum merupakan pusat informasi lokal dari semua jenis ilmu pengetahuan dan informasi yang tersedia untuk para penggunanya. Sebagai suatu institusi netral, perpustakaan umum menyediakan layanan informasi dan bahan bacaan kepada masyarakat, tanpa membedakan suku bangsa, agama yang dianut, jenis kelamin, latar belakang dan tingkat sosial, umur dan pendidikan serta perbedaan lainnya. Perpustakaan umum memiliki tujuan utama yaitu memberikan kesempatan bagi masyarakat umum untuk membaca bahan pustaka yang dapat membantu meningkatkan mereka ke arah kehidupan yang lebih baik, menyediakan sumber informasi yang cepat, tepat, 
murah bagi masyarakat, serta membantu warga untuk mengembangkan kemampuan yang dimilikinya sehingga yang bersangkutan akan bermanfaat bagi masyarakat sekitarnya.

Perpustakaan umum menempati ruang gerak yang cukup strategis di tengah-tengah masyarakat sebab berfungsi melayani semua lapisan masyarakat untuk memperoleh dan meningkatkan ilmu pengetahuan. Namun jika melihat kondisi perpustakaan umum di negara kita masih memprihatinkan. $\mathrm{Hal}$ ini mudah diidentifikasi dengan kenyataan banyak warga masyarakat yang tidak memanfaatkan perpustakaan. Jika dilihat dan dikaji, jumlah anggota perpustakaan-perpustakaan umum daerah tidak sebanding dengan jumlah penduduk yang ada di daerah-daerah tersebut.

Bertolak belakang dengan kondisi perpustakaan-perpustakaan daerah pada umumnya di Indonesia, Perpustakaan Daerah Kabupaten Bantul justru ramai dikunjungi masyarakat. Bahkan sesudah terjadi gempa bumi Kabupaten Bantul pada tahun 2006, jumlah pengunjung perpustakaan daerahnya masih lebih banyak dibandingkan dengan pengunjung Perpustakaan Umum Kabupaten Badung dan Kabupaten Subang dalam tahun yang sama. Banyaknya masyarakat yang berkunjung ke perpustakaan tidak lepas dari berbagai strategi yang diterapkan Perpustakaan Daerah Kabupaten Bantul dalam meningkatkan kualitas layanannya. Oleh sebab itu, penulis ingin meneliti tentang Strategi Peningkatan Manfaat Perpustakaan Daerah di Daerah KabupatenBantul. Tujuan dari penelitian ini adalah untuk mengetahui mengapa perpustakaan daerah banyak dimanfaatkan masyarakat dan untuk mengetahui strategi yang digunakan untuk peningkatan manfaat perpustakaan daerah.

\section{B. TINJAUAN PUSTAKA}

\section{Peranan Perpustakaan Umum}

Perpustakaan umum amat penting bagi kehidupan kultural dan kecerdasan bangsa karena perpustakaan umum merupakan satu-satunya pranata kepustakawanan yang dapat diraih umum. Demikian pentingnya perpustakaan umum bagi kecerdasan bangsa sehingga badan PBB yang bergerak dalam bidang perpustakaan yaitu United Nations Educational, Scientific dan Cultural Organization (UNESCO) mengeluarkan manifesto perpustakaan umum. Unisco menyatakan bahwa perpustakaan umum mempunyai 4 tujuan utama, yaitu:

1. Memberikan kesempatan bagi umum untuk membaca bahan pustaka yang dapat membantu meningkatkan mereka kearah kehidupan yang lebih baik.

2. Menyediakan sumber informasi yang cepat, tepat, murah bagi masyarakat, terutama informasi mengenai topik yang berguna bagi mereka dan yang sedang hangat dalam kalangan masyarakat.

3. Membantu warga mengembangkan kemampuan yang dimilikinya sehingga yang bersangkutan akan bermanfaat bagi masyarakat sekitarnya, sejauh kemampuan tersebut dapat dikembangkan dengan bantuan bahan pustaka.Fungsi ini sering disebut fungsi pendidikan perpustakaan umum, lebih tepat disebut sebagai pendidikan berkesinambungan ataupun pendidikan seumur hidup. Pendidikan ini hanya dapat dilakukan perpustakaan umum karena perpustakaan umum merupakan satusatunya pranata kepustakawaan yang terbuka untuk umum.

4. Bertindak selaku agen kultural artinya perpustakaan umum merupakan pusat utama kehidupan budaya masyarakat sekitarnya. Perpustakaan umum bertugas menumbuhkan apresiasi budaya masyarakat sekitarnya dengan cara penyelenggaraan pameran budaya, ceramah, pemutaran film dan penyediaan informasi yang dapat meningkatkan keikutsertaan, kegemaran dan apresiasi masyarakat terhadap segala bentuk seni budaya.

Manifesto tersebut menekankan pentingnya perpustakaan umum bagi masyarakat, khususnya bagi mereka yang telah meninggalkan bangku 
sekolah, sehingga UNESCO menyarankan bahwa bila sebuah tempat berpenduduk sebanyak 50.000 jiwa atau lebih maka di tempat tersebut harus dibangun sebuah perpustakaan umum (Sulistyo, 1994.35)

Sutarno (2003:55-56) mengatakan bahwa peranan sebuah perpustakaan adalah bagian dari tugas pokok yang harus dijalankan di dalam perpustakaan. Oleh karena itu peranan yang harus dijalankan ikut menentukan dan mempengaruhi tercapainya misi dan tujuan perpustakaan.

\section{Pelayanan Pengguna Perpustakaan}

Layanan informasi perpustakaan dalam arti luas adalah bagaimana menjangkau pemakai secara geografis, mendekatkan perpustakaan kepada pemakai dan mendistribusikan informasi kepada pemakai dalam bentuk interaksi antara petugas dan pemakai, dan transformasi ilmu pengetahuan dari sumbernya kepada pemakai (Sutarno, 2005:113).

Menurut Mustafa dalam Rahayuningsih F, dkk. (2007:86-87) karakteristik layanan pengguna meliputi koleksi, fasilitas, sumber daya manusia, dan layanan perpustakaan. Layanan di perpustakaan idealnya dapat lebih memikat, bersahabat, cepat, dan akurat. Ini berarti orientasi pelayanan perpustakaan harus didasarkan pada kebutuhan pengguna, antisipasi perkembangan teknologi informasi dan pelayanan yang ramah, dengan kata lain menempatkan pengguna sebagai salah satu faktor penting yang mempengaruhi kebijakan pada suatu perpustakaan. Kesan kaku pelayanan di perpustakaan harus dieliminir sehingga perpustakaan berkesan lebih manusiawi.

\section{Pemanfaatan Perpustakaan}

Michael J. Menov dalam Conceptual Model for Measure seperti dikutip Rohmiyati (2006:16) mengatakan bahwa pemanfaatan layanan informasi bagi pemakai perpustakaan dipengaruhi oleh beberapa faktor, yaitu:

a. Tujuan pemanfaatan perpustakaan

b. Kepentingan pemakai perpustakaan

c. Kepuasan pada berbagai layanan perpustakaan, kemudahan dan biaya dalam menggunakan fasilitas layanan perpustakaan.

Setiap orang yang berkunjung ke perpustakaan mempunyai tujuan dan kepentingan yang berbeda. Pada umumnya orang yang berkunjung ke perpustakaan adalah untuk mencari informasi. Menurut Sutarno (2003:26) tujuan orang berkunjung ke perpustakaan adalah:

a. Untuk mengikuti peristiwa dan perkembangan dunia terakhir melalui berbagai sumber bacaan.

b. Untuk mendapatkan pengajaran dan pendidikan. Melalui perpustakaan orang dapat belajar secara otodidak atau belajar sendiri, terutama bagi mereka yang tidak sedang duduk di bangku sekolah/kuliah. Sebaliknya bagi yang sedang mengikuti pendidikan formal, belajar di perpustakaan merupakan salah satu cara untuk menambah dan meningkatkan ilmu pengetahuan. Dengan demikian diharapkan mampu menyelesaikan pendidikannya tepat waktu dan memperoleh hasil yang memuaskan.

c. Selain dapat memupuk kemampuan dan kepercayaan diri setelah menguasai banyak informasi dan ilmu pengetahuan, seseorang yang rajin ke perpustakaan akan memperoleh kenikmatan dan kepuasan, sebab kebutuhan jiwanya dapat diisi dengan apa yang ia senangi.

Banyak faktor yang memengaruhi pemanfaatan perpustakaan oleh masyarakat. Pada umumnya faktor-faktor tersebut dapat digolongkan dalam dua aspek yaitu aspek yang ada pada perpustakaan dan aspek masyarakat sebagai pemustaka. Aspek yang ada pada perpustakaan yaitu situasi dan kondisi perpustakaan seperti sarana dan prasarana yang memadai, koleksi yang beragam, pelayanan yang memuaskan dan kegiatan sosialisasi yang rutin dilakukan dapat mendorong masyarakat untuk berkunjung ke perpustakaan. Sedangkan aspek pemustaka dipengaruhi adanya perbedaan minat, bakat, kemauan, dan kebutuhan yang dimiliki setiap individu (Rohmiyati, 2006:17). 
Tingkat pemanfaatan perpustakaan oleh masyarakat, dapat juga dipengaruhi oleh tingginya minat baca masyarakat. Minat baca seseorang dapat diartikan sebagai kecenderungan hati yang tinggi orang tersebut terhadap suatu sumber bacaan tertentu (Sutarno, 2003:19).

\section{Lingkungan Strategis Organisasi}

Lingkungan strategis organisasi terbagi atas dua, yaitu lingkungan internal dan ingkungan eksternal. Analisa kedua lingkungan tersebut dapat dijadikan dasar dalam perumusan strategi guna mencapai tujuan organisasi.

\section{a. Konsep Strategi}

Strategi merupakan suatu rencana tindakan jangka panjang yang luas dan bersifat umum yang menentukan rumusan kebijakan organisasi dan program-program tindakan (Anthony, 1990 dalam Supriyanto, 2005). Strategi yang dikembangkan meliputi kebijakan untuk menuntun arah tindakan maupun programprogram kegiatan untuk mencapai tujuan. Strategi dapat dipandang sebagai pola tujuan, kebijakan, program, tindakan, keputusan atau alokasi sumber daya yang menidefenisikan bagaimana organisasi itu, apa yang dikerjakan organisasi, dan mengapa organisasi melakukannya (Bryson, 1999:189). Oleh karena itu strategi merupakan perluasan misi guna menjembatani organisasi (atau komunitas) dan lingkungannya. Strategi biasanya dikembangkan untuk mengatasi isu strategis. Strategi menjelaskan respon organisasi terhadap pilihan kebijakan pokok (jika pendekatan sasaran bagi isu yang diambil). Strategi akan dikembangkan untuk mencapai sasaran; atau jika pendekatan visi keberasilan yang diambil Strategi akan dikembangkan untuk mencapai visi tersebut. Empat tingkat dasar strategi meliputi:

a. Strategi besar bagi organisasi secara keseluruhan

b. Strategi unit perencanaan publik strategis (UPPS) atau unit perencanaan nirlaba strategis (UPNS). Namun, perlu dicatat bahwa jika organisasi secara keseluruhan dan
UPPS maupun UPNS sinonim, dua kategori pertama akan sama; jika strategi UPPS atau UPNS mungkin menjadi divisi, departemen, atau unit dari organisasi yang lebih besar.

c. Strategi program atau pelayanan.

d. Strategi fungsional (seperti keuangan, penempatan staf, fasilitas, dan usaha pendapatan).

\section{b. Lingkungan Strategis Organisasi}

Lingkungan sebagaimana umum diartikan meliputi kondisi, situasi keadaan, peristiwa, dan pengaruh-pengaruh yang mengelilingi dan mempengaruhi perkembangan organisasi (Salusu, 1996:319). Jadi setiap organisasi senantiasa berinteraksi dengan lingkungan. Organisasi kadang-kadang dapat mempengaruhi lingkungan, tetapi yang paling umum adalah organisasi lebih banyak dipengaruhi oleh lingkungan. Lingkungan organisasi dalam garis besarnya terdiri atas dua struktur yaitu lingkungan internal dan lingkungan eksternal (Suharyanto:2005).

\section{c. Analisis Lingkungan Strategis}

Tujuan analisis lingkungan organisasi baik internal maupun eksternal adalah menghasilkan informasi yang sangat penting bagi kelangsungan dan kemakmuran rganisasi, yaitu informasi mengenai kekuatan dan kelemahan terkait dengan peluang dan ancaman yang dihadapi. Analisis terhadap kekuatan (strength), kelemahan (weaknesses), peluang (opportunities), dan ancaman (threats) dikenal dengan analisis SWOT. Analisis SWOT merupakan identifikasi berbagai faktor secara sistematis untuk merumuskan strategi organisasi. Analisis SWOT didasarkan pada logika yang dapat memaksimalkan kekuatan dan peluang secara bersamaan dapat meminimalkan kelemahan dan ancaman.

\section{METODE PENELITIAN}

Metode penelitian yang digunakan adalah studi kasus di Perpustakaan Daerah Kabupaten Bantul. Sampel yang digunakan berasal dari 
pengelola perpustakaan yang terdiri dari Kepala Perpustakaan, Kepala Sub Bagian Tata Usaha, Kepala Seksi Akuisisi dan Pengolahan, Kepala Seksi Layanan Pustaka dan Informasi, Kepala Seksi Layanan Perpustakaan Keliling, pustakawan dan staf, serta masyarakat yang berkunjung dan memanfaatkan Perpustakaan Daerah Kabupaten Bantul.

Teknik pengumpulan data yang dilakukan melalui observasi langsung aktivitas layanan yang diberikan di Kantor Perpustakaan Daerah Kabupaten Bantul, wawancara dengan pengelola perpustakaan dan pengunjung perpustakaan, penyebaran kuesioner kepada pengunjung perpustakaan, dan studi pustaka.

Data yang diperoleh dari penelitian kepustakaan maupun penelitian lapangan dianalisis secara deskriptif kualitatif, dengan melakukan analisis SWOT terhadap faktor lingkungan internal dan eksternal perpustakaan yang akan menjadi dasar dalam perumusan strategi yang diterapkan di Perpustakaan Daerah Kabupaten Bantul.

\section{HASIL PENELITIAN}

Faktor-faktor yang mempengaruhi pemanfaatan perpustakaan oleh masyarakat dapat digolongkan dalam dua aspek yaitu faktor internal perpustakaan atau aspek yang ada pada perpustakaan dan faktor eksternal perpustakaan atau aspek yang berada di luar perpustakaan. Faktor internal Perpustakaan Daerah Kabupaten Bantul terdiri sumber daya manusia berkualitas, koleksi yang beragam dan berkualitas, sarana dan prasarana yang memadai, pelayanan yang memuaskan, lokasi perpustakaan yang strategis, dan kegiatan promosi rutin yang dilakukan dapat mendorong masyarakat untuk berkunjung ke perpustakaan. Sedangkan yang termasuk faktor eksternal perpustakaan yaitu pemerintah, mitra perpustakaan, masyarakat pengguna perpustakaan, dan teknologi informasi.

Upaya yang dilakukan peneliti untuk menganalisis faktor/lingkungan internal dan eksternal perpustakaan daerah adalah dengan menggunakan analisis SWOT. Analisis SWOT digunakan untuk mengenali dan menganalisis faktor internal (kekuatan dan kelemahan) dan faktor eksternal (peluang dan ancaman) yang akan menjadi dasar dalam perumusan strategi perpustakaan. Dari identifikasi faktor internal dan eksternal Kantor Perpustakaan Daerah Kabupaten Bantul, diperoleh variabel- variabel sebagai berikut:

\begin{tabular}{|c|c|}
\hline Internal & Ekstemal \\
\hline Kekuatan (strengths) & Peluang (opportunities) \\
\hline $\begin{array}{ll}\text { 1. } & \text { Kualitas SDM } \\
\text { 2. } & \text { Ketersediaan koleksi } \\
\text { 3. } & \text { Kenyamanan } \\
& \text { perpustakaan } \\
\text { 4. } & \text { Kestrategisan letak } \\
\text { kantor perpustakaan }\end{array}$ & $\begin{array}{l}\text { 1. Pemerintah } \\
\text { 2. Mitra perpustakaan } \\
\text { 3. Pemanfaatan Teknologi } \\
\text { Informasi }\end{array}$ \\
\hline Kelemahan (weaknesses) & Ancaman (threaths) \\
\hline $\begin{aligned} & \text { 1. } \text { Keterbatasan } \\
& \text { sarana dan } \\
& \text { prasarana } \\
& \text { 2. } \\
& \text { Keterbatasan } \\
& \text { anggaran } \\
& \text { 3. Minimnya jumlah } \\
& \text { pegawai } \\
& \text { 4. Promosi } \\
& \text { perpustakaan }\end{aligned}$ & 1. Bidang usaha sejenis \\
\hline
\end{tabular}

Setelah mengidentifikasi faktor internal dan eksternal perpustakaan yang berupa kekuatan, kelemahan, peluang dan ancaman, kemudian dibuat klasifikasi analisis faktor internal (KAFI) dan klasifikasi analisis faktor eksternal (KAFE) yang dapat dirangkum dalam matriks SWOT, sebagai berikut:

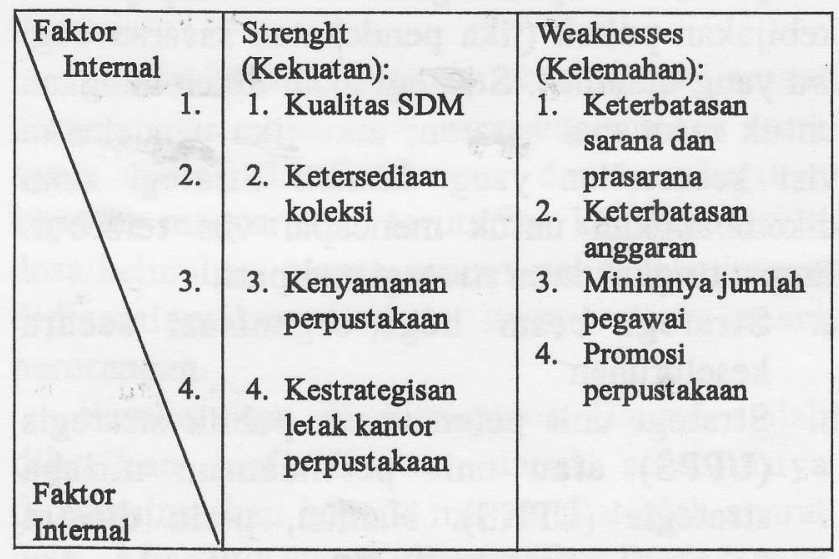




\begin{tabular}{|c|c|c|}
\hline $\begin{array}{l}\text { Opportunities } \\
\text { (Peluang): } \\
\text { a. Pemerintah } \\
\text { b. Mitra } \\
\text { perpustakaan } \\
\text { c. Pemanfaatan } \\
\text { Teknologi } \\
\text { Informasi }\end{array}$ & $\begin{array}{l}\text { 1. Optimalkan } \\
\text { kualitas SDM, } \\
\text { ketersediaan } \\
\text { koleksi, } \\
\text { dukungan mitra, } \\
\text { dan pemanfaatan } \\
\text { TI untuk } \\
\text { memberikan } \\
\text { pelayanan } \\
\text { maksimal kepada } \\
\text { pengguna } \\
\text { perpustakaan/pe } \\
\text { mustaka } \\
\text { 2. Manfaatkan } \\
\text { kenyamanan dan } \\
\text { kestrategisan } \\
\text { letak } \\
\text { perpustakaan, } \\
\text { dukungan } \\
\text { pemerintah, dan } \\
\text { pemanfaatan } \\
\text { Teknologi } \\
\text { Informasi untuk } \\
\text { menarik } \\
\text { masyarakat } \\
\text { berkunjung ke } \\
\text { perpustakaan }\end{array}$ & $\begin{array}{l}\text { 1. Atasi } \\
\text { keterbatasan } \\
\text { sarana dan } \\
\text { prasarana, } \\
\text { anggaran dan } \\
\text { promosi } \\
\text { perpustakaan } \\
\text { dengan } \\
\text { memanfaatkan } \\
\text { mitra } \\
\text { perpustakaan, } \\
\text { sehingga kegiatan } \\
\text { kebutuhan } \\
\text { pengguna tetap } \\
\text { terpenuhi dan } \\
\text { promosi } \\
\text { perpustakaan } \\
\text { dapat rutin } \\
\text { dilakukan. } \\
\text { 2. Atasi minimnya } \\
\text { jumlah pegawai } \\
\text { dengan } \\
\text { memanfaatkan } \\
\text { teknologi } \\
\text { informasi yang } \\
\text { tersedia, sehingga } \\
\text { masyarakat dapat } \\
\text { tetap terlayani } \\
\text { secara baik }\end{array}$ \\
\hline $\begin{array}{l}\text { Threats } \\
\text { (Ancaman): } \\
\text { a. Bidang } \\
\text { usaha sejenis }\end{array}$ & $\begin{array}{l}\text { 1. Manfaatkan } \\
\text { kualitas SDM, } \\
\text { ketersediaan } \\
\text { koleksi, Kenya- } \\
\text { manan, dan } \\
\text { kestrategisan } \\
\text { letak } \\
\text { perpustakaan } \\
\text { untuk } \\
\text { mengatasi } \\
\text { ancaman dari } \\
\text { bidang usaha } \\
\text { sejenis }\end{array}$ & $\begin{array}{l}\text { 1. Dengan } \\
\text { keterbatasan } \\
\text { sarana dan } \\
\text { prasarana, } \\
\text { anggaran dan } \\
\text { jumlah pegawai, } \\
\text { dan promosi } \\
\text { perpustakaan } \\
\text { tetap berusaha } \\
\text { member } \\
\text { pelayanan } \\
\text { semaksimal } \\
\text { mungkin untuk } \\
\text { menghindari } \\
\text { persepsi negatif } \\
\text { dari masyarakat, } \\
\text { sehingga } \\
\text { masyarakat masih } \\
\text { tetap } \\
\text { memanfaatkan } \\
\text { perpustakaan dan } \\
\text { tidak berpaling ke } \\
\text { bidang usaha } \\
\text { sejenis. }\end{array}$ \\
\hline
\end{tabular}

Berdasarkan matriks SWOT Perpustakaan Daerah Kabupaten Bantul, diperoleh 7 (tujuh) isu strategis untuk peningkatan manfaat perpustakaan, yaitu:

1. Meningkatkan kualitas SDM perpustakaan;

2. Meningkatkan jumlah koleksi sesuai minat dan kebutuhan pengguna;

3. Membangun kondisi perpustakaan yang nyaman;

4. Meningkatkan kualitas layanan dengan menerapkan teknologi informasi di perpustakaan;

5. Memberikan layanan yang maksimal kepada masyarakat untuk mengatasi ancaman dari bidang usaha sejenis;

6. Membangun kemitraan untuk mengatasi kekurangan sarana dan prasarana serta anggaran dari pemerintah daerah;

7. Meningkatkan pemahaman masyarakat tentang keberadaan dan manfaat perpustakaan melalui kegiatan promosi perpustakaan secara rutin.

Untuk point 4 (empat) dan 5 (lima) dapat digabungkan menjadi isu memberikan layanan yang maksimal kepada masyarakat. Keenam isu strategis tersebut menjadi dasar dalam perumusan strategi peningkatan manfaat Perpustakaan Daerah Kabupaten Bantul.

\section{Meningkatkan kualitas SDM perpustakaan}

Sumber daya manusia (SDM) merupakan salah satu unsur utama dalam pencapaian keberasilan pelayanan guna peningkatan manfaat perpustakaan. Oleh sebab itu SDM perpustakaan perlu dikembangkan dan ditingkatkan kemampuannya, yang hasilnya diharapkan mampu meningkatkan produktivitas dan kinerja perpustakaan.

Jika ditinjau dari segi tingkat pendidikan, SDM Perpustakaan Daerah Kabupaten Bantul boleh dikatakan cukup berkualitas. Hal ini karena lebih dari $50 \%$ pegawai berpendidikan sarjana (S1 sebanyak 10 orang atau $28,57 \%$ dan sarjana muda/diploma sebanyak 9 orang atau $25,71 \%$ ). Akan tetapi dari 35 jumlah pegawai Perpustakaan 
Daerah Kabupaten Bantul, hanya 6 (enam) pustakawannya. Dari keenam pustakawan tersebut hanya 4 (empat) orang yang menempuh pendidikan formal kepustakawan melalui jalur diploma II dan diploma III, sedangkan 2 (dua) sisanya hanya menempuh pelatihan khusus kepustakawanan.

Selain kekurangan pustakawan, penataan pegawai pada unit- unit kerja di Kantor Perpustakaan Daerah Kabupaten Bantul dapat dikatakan belum maksimal. Hal ini karena jumlah pegawai pada bagian tata usaha (TU) lebih banyak dibandingkan pada bagian layanan bahan pustaka dan informasi. Walau demikian pegawai bagian tata usaha turut dilibatkan dalam kegiatan layanan pengguna, sehingga mereka perlu mendapat pengetahuan tentang layanan pengguna terutama layanan sirkulasi.

Untuk mengatasi masalah SDM, Perpustakaan Daerah Kabupaten Bantul menerapkan strategi manajemen SDM sebagai berikut:

a. Penataan pegawai pada unit- unit kerja dalam kantor perpustakaan. Dalam upaya memberikan pelayanan maksimal kepada masyarakat, manajemen Perpustakaan Daerah Kabupaten Bantul berupaya menata pegawainya terutama dalam pembagian tugas layanan perpustakaan keliling, layanan sore dan Minggu. Hal ini agar tidak hanya pegawai bagian layanan saja yang merasakan kerja di luar jam kantor, akan tetapi semua pegawai perpustakaan dilibatkan dengan menggunakan sistem rolling.

b. Diupayakan pengiriman pegawai untuk melanjutkan pendidikan (D3,S1). Bagi pegawai yang berpendidikan SMA atau sederajat diupayakan untuk melanjutkan pendidikan kepustakawanan ke tingkat sarjana (baik sarjana muda maupun strata satu). Hal ini merupakan salah satu cara untuk mengatasi kekurangan tenaga pustakawan.

c. Pengiriman pegawai untuk mengikuti pelatihan, magang dan studi banding. Adanya keterbatasan anggaran pemerintah daerah (pemda) untuk membiayai pendidikan pegawai lingkup pemda membuat manajemen Perpustakaan Daerah Kabupaten Bantul berupaya menyediakan anggaran untuk mengikutsertakan pegawainya dalam kegiatan pelatihan, magang dan studi banding. Salah satu syarat pegawai yang dipilih untuk mengikuti kegiatan tersebut adalah pegawai yang berprestasi, rajin dan disiplin. Hal ini merupakan salah satu bentuk motivasi agar pegawai lebih giat dalam bekerja.

d. Pelatihan pegawai tentang penggunaan teknologi informasi (TI). Perpustakaan Daerah Kabupaten Bantul telah menerapkan TI untuk kegiatan administrasi kantor, pengolahan koleksi, layanan sirkulasi dan internet. Oleh sebab itu pegawai yang tidak atau kurang memahami penggunaan komputer dan internet diikutsertakan dalam pelatihan TI. Seperti yang dituturkan Kepala Perpustakaan Daerah Kabupaten Bantul "wajib hukumnya bagi pegawai perpustakaan untuk mengetahui komputer dan internet".

e. Menyiapkan SDM sesuai dengan program pengembangan pelayanan perpustakaan. Pelayanan perpustakaan berupaya mengikuti kebutuhan pengguna dan kemajuan zaman. Seperti saat ini penggunaan TI sudah menjadi keharusan setiap perpustakaan yang ingin memberikan layanan yang maksimal kepada penggunanya. Oleh sebab itu seperti yang telah dijelaskan sebelumnya SDM Perpustakaan Daerah Kabupaten Bantul dibekali dengan pengetahuan TI karena saat ini kegiatan layanan perpustakaan telah menggunakan TI.

f. Memperbaiki budaya kerja dan meningkatkan komitmen pegawai dengan mengadakan kegiatan yang melibatkan seluruh pegawai seperti rekreasi bersama, memberi reward kepada pegawai yang rajin/berprestasi dengan mempromosikan jabatan, diikutkan dalam pelatihanpelatihan, usulan kenaikan pangkat tepat 
waktu dan dimasukkan dalam tim kegiatan perpustakaan;

g. Menggalang komitmen untuk bekerja sama dalam memberi pelayanan maksimal kepada masyarakat, dengan mengadakan pertemuan rutin secara formal dan non formal untuk seluruh pegawai seperti melakukan meeting non formal saat apel pagi dengan menyampaikan masalah-masalah yang ada serta berusaha untuk mencari solus i yang tepat. Jika masalah tersebut perlu penanganan serius, maka akan dilanjutkan dengan rapat formal.

\section{Meningkatkan jumlah koleksi sesuai minat dan kebutuhan pengguna}

Koleksi bahan pustaka yang dimiliki Kantor Perpustakaan Daerah Kabupaten Bantul sampai tahun 2008 adalah sebesar 34.214 judul buku at au sebanyak 75.060 eksemplar, dengan penambahan buku setiap tahunnya hampir mencapai 3.000 judul dan jumlah eksemplar mencapai 17.000 lebih. Koleksi bahan pustaka yang banyak dimanfaatkan pengunjung Perpustakaan Daerah Kabupaten Bantul adalah jenis koleksi agama, ilmu-ilmu sosial, ilmu-ilmu terapan, kesenian, dan golongan sastra (termasuk koleksi fiksi).

Mengingat koleksi bahan pustaka merupakan salah satu unsur utama yang dapat menarik masyarakat untuk memanfaatkan perpustakaan, manajemen Perpustakaan Daerah Kabupaten Bantul berusaha menyiapkan koleksi yang sesuai dengan minat dan kebutuhan masyarakat Bantul. Strategi yang digunakan untuk mengatasi hal tersebut adalah:

a. Menyediakan buku permintaan koleksi, kotak saran dan e-mail sebagai sarana menampung permintaan koleksi masyarakat. Permintaan koleksi dari masyarakat tersebut menjadi salah satu dasar kebijakan pengadaan koleksi di Perpustakaan Daerah Kabupaten Bantul selain dengan melihat statistik peminjaman koleksi yang paling banyak dipinjam/diminati.

b. Meningkatkan jumlah koleksi sesuai minat dan kebutuhan masyarakat. Penambahan koleksi bahan pustaka diupayakan meningkat secara signifikan setiap tahunnya dan berdasarkan minat dan kebutuhan masyarakat yang dapat dilihat dari buku permintaan koleksi, kotak saran dan e-mail serta koleksi yang sering dipinjam pengguna.

c. Diupayakan koleksi yang diadakan merupakan koleksi terbaru dan mengikuti kemajuan zaman, serta dapat meningkatkan pengetahuan, keimanan, keterampilan dan menghimbur masyarakat.

d. Menyediakan porsi anggaran pengadaan koleksi yang cukup besar, sekitar 10-15\% dari anggaran perpustakaan atau $30 \%$ dari anggaran operasional perpustakaan.

\section{Membangun kondisi perpustakaan yang nyaman}

Kondisi sarana prasarana dan lingkungan perpustakaan sangat berpengaruh dalam peningkatan manfaat perpustakaan. Kondisi yang nyaman, tenang serta ditunjang dengan sarana dan prasarana yang mendukung, akan membuat pengunjung betah di perpustakaan. Hal ini akan membuat mereka datang kembali untuk memanfaatkan perpustakaan.

Perpustakaan Daerah Kabupaten Bantul merupakan perpustakaan umum kabupaten yang melayani seluruh lapisan masyarakat tanpa membedakan usia, pendidikan, pekerjaan, agama, golongan, suku dll. Dengan beragamnya pengunjung perpustakaan maka perpustakaan berusaha menciptakan suasana yang sesuai dengan kondisi pengunjung tersebut, sehingga pengunjung merasa nyaman berada di perpustakaan. Strategi yang digunakan untuk menciptakan kondisi nyaman perpustakaan, sebagai berikut:

a. Menyediakan sarana pendingin ruangan seperti AC dan kipas serta fasilitas umum seperti toilet dan mushola.

b. Menciptakan kondisi tenang bagi pengunjung perpustakaan yang memerlukan konsentrasi dalam membaca dengan 
menyediakan zona sepi yang terpisah dengan zona rame. Perpustakaan Daerah Kabupaten Bantul membagi zona perpustakaan menjadi zona sepi dan zona ramai. Zona sepi merupakan tempat koleksi umum yang terletak di lantai 1 (satu) sedangkan zona rame merupakan tempat koleksi anak yang terletak di lantai 2 (dua).

- Zona ramai merupakan tempat koleksi anak dibuat lesehan sehingga anak-anak bebas bergerak tanpa dihalangi jejeran kursi.

- Menyediakan tempat parkir untuk pengunjung perpustakaan yang cukup luas dan gratis.

c. Meningkatkan program pengadaan dan pemeliharaan sarana dan prasarana layanan pengguna.

\section{Memberikan layanan yang maksimal kepada masyarakat}

Kantor Perpustakaan Daerah Kabupaten Bantul terbuka untuk umum serta melayani masyarakat yang memerlukan akses informasi dan bahan-bahan pustaka. Sistem layanan perpustakaan yang digunakan adalah open access system atau sistem layanan terbuka, yaitu semua pengguna baik yang sudah menjadi anggota ataupun yang belum menjadi anggota diberi kebebasan mencari, memilih dan mengambil sendiri buku yang diinginkan secara langsung di rak buku yang telah disediakan. Hal ini bertujuan agar pengguna perpustakaan dapat menentukan dan memilih beragam koleksi sesuai dengan kebutuhannya.

Perpustakaan Daerah Kabupaten Bantul mengupayakan pelayanan berorientasi pengguna atau dengan kata lain menempatkan pengguna sebagai salah satu faktor penting yang mempengaruhi kebijakan perpustakaan. Dengan memberikan pelayanan yang maksimal kepada masyarakat, diharapkan perpustakaan akan tetap ramai dikunjungi.

Adapun strategi yang digunakan dalam pelayanan pengguna perpustakaan, adalah: a. Membudayakan sikap "ramah, sopan, ceria dan seyum" pada petugas layanan pustaka dan informasi saat berinteraksi dengan pengguna. Jika ada pengunjung yang datang maka akan disapa dengan kalimat "Apa yang dapat kami bantu?"

b. Mengarahkan petugas layanan, agar bertanggung jawab dan terampil dalam melayani pengguna perpustakaan.

c. Diupayakan pengguna perpustakaan dilayani dengan mudah dan cepat.

d. Keanggotaan perpustakaan dan denda keterlambatan gratis.

e. Waktu layanan setiap hari dan sampai sore hari. Hal ini bertujuan agar masyarakat yang tidak sempat berkunjung ke perpustakaan pada jam kerja dan sekolah, dapat memanfaatkan perpustakaan diwaktu senggang atau setelah melakukan aktivitas kerja atau sekolah.

f. Pengadaan sarana layanan sirkulasi dan penelusuran informasi berbasis teknologi informasi (TI) untuk kemudahan pelayanan. Perpustakaan Daerah Kabupaten Bantul menggunakan TI dalam layanan sirkulasi, seperti keanggotaan, peminjaman, pengembalian dan penelusuran koleksi (OPAC).

g. Pembangunan Wifi/hot spot untuk meningkatkan layanan internet. Hal ini untuk mengatasi keterbatasan unit komputer untuk layanan internet ditengah maraknya pengguna perpustakaan yang ingin menggunakan internet.

5. Membangun kemitraan untuk mengatasi kekurangan sarana dan prasarana serta anggaran dari Pemerintah Daerah

Anggaran Perpustakaan Daerah Kabupaten Bantul yang diberikan pemerintah daerah lewat APBD tergolong besar, akan tetapi sebagai organisasi yang sedang berkembang dan berusaha memberi layanan maksimal dan merata kepada seluruh masyarakat Bantul, perpustakaan daerah masih merasa kewalahan. Hal ini dikarenakan 
adanya keterbatasan yang dihadapai perpustakaan, diantaranya: anggaran, tenaga, sarana prasarana, dan koleksi.

Dalam upaya pengembangan perpustakaan dan meningkatkan kualitas layanannya, Perpustakaan Daerah Kabupaten Bantul menjaring mitra kerjasama dari lembaga atau organisasi non pemerintah. Mitra perpustakaan sangat membantu Perpustakaan Daerah Kabupaten Bantul dalam mengatasi masalah kekurangan anggaran dan sarana prasarana. Misalnya untuk kegiatan promosi, perpustakaan bekerja sama dengan TVRI, Jogja TV dan RB TV, RRI, Bantul FM dan Radio Persatuan Pembangunan; untuk penambahan koleksi bahan pustaka, genset dan motor pintar, perpustakaan berkerja sama dengan BPD Cab. Bantul, Solidaritas Isteri Kabinet Indonesia Bersatu (SIKIB), Bupati Bantul, dll; dan yang paling anyar adalah pembangunan gedung Perpustakaan Daerah Kabupaten Bantul yang baru serta sebagian perabot kantor merupakan bantuan dari Korea Overseas Volunteers Association (KOVA).

Srategi yang digunakan Perpustakaan Daerah Kabupaten Bantul dalam menjalin kerja sama dengan mitra perpustakaan adalah sebagai berikut:

a. Ikut serta sebagai anggota organisasi atau forum kepustakawanan nasional seperti Ikatan Pustakawan Indonesia (IPI).

b. Ikut serta dalam kegiatan-kegiatan yang diselenggarakan organisasi atau forum kepustakawanan nasional dan diupayakan yang berskala internasional.

c. Mengadakan koordinasi dan sosialisasi dengan lembaga atau organisasi/orang yang berkompeten dengan perpustakaan, seperti Bupati, tokoh masyarakat, BPD, SIKIB, NGO, organisasi-organisasi pemberitaan seperti media cetak dan elektronik, dll.

6. Meningkatkan pemahaman masyarakat tentang keberadaan dan manfaat perpustakaan melalui kegiatan promosi secara rutin
Setiap perpustakaan akan menghadapi permasalahan jika keberadaannya tidak/kurang dikenal masyarakat. Apabila masyarakat kurang memberi perhatian, dampak selanjutnya perpustakaan akan sepi pengunjung. Oleh sebab itu perlu dilakukan promosi perpustakaan, agar keberadaannya diketahui, dan dapat menarik masyarakat untuk berkunjung dan memanfaatkan perpustakaan.

Perpustakaan Daerah Kabupaten Bantul melakukan promosi secara rutin untuk memberitahukan masyarakat akan keberadaan dan manfaat perpustakaan melalui koleksi, fasilitas, dan produk/layanan yang disediakan. Promosi perpustakaan dilakukan melalui media cetak, elektronik, pameran, kegiatan-kegiatan lomba perpustakaan maupun melalui perpustakaan keliling. Strategi yang dilakukan antara lain:

a. Menyusun dan melaksanakan program penyebarluasan sumber-sumber informasi (promosi) perpustakaan baik melalui media cetak, elektronik, pameran, kegiatankegiatan lomba perpustakaan maupun melalui perpustakaan keliling.

b. Bekerjasama dengan Dinas Pendidikan Kab. Bantul, perangkat desa, lembaga desa, tokoh masyarakat, RT, RW, dan mahasiswa $\mathrm{KKN}$ untuk memasyarakatkan perpustakaan;

c. Mengupayakan agar kegiatan promosi rutin dilakukan, seperti melalui siaran Radio Bantul FM yang dilakukan rutin 1-2 kali sebulan.

\section{E. KESIMPULAN DAN SARAN}

Berdasarkan hasil penelitian dan pembahasan yang telah diuraikan maka dapat disimpulkan bahwa:

1. Faktor internal yang memengaruhi pemanfaatan Perpustakaan Daerah Kabupaten Bantul terdiri sumber daya manusia berkualitas, koleksi yang beragam dan berkualitas, sarana dan prasarana yang memadai, pelayanan yang memuaskan, lokasi perpustakaan yang strategis, dan 
kegiatan promosi yang rutin dilakukan. Sedangkan yang termasuk faktor eksternal perpustakaan yaitu pemerintah, mitra perpustakaan, masyarakat pengguna perpustakaan, dan teknologi informasi.

2. Analisis SWOT faktor internal dan eksternal Perpustakaan Daerah Kabupaten Bantul diperoleh hasil: (a) Kekuatan perpustakaan terdiri dari kualitas SDM, ketersediaan koleksi, kenyamanan perpustakaan, dan kestrategisan letak kantor perpustakaan; (b) Kelemahan perpustakaan terdiri dari keterbatasan sarana dan prasarana, keterbatasan anggaran, minimnya jumlah pegawai, dan promosi perpustakaan; (c) Peluang perpustakaan terdiri dari dukungan pemerintah, mitra perpustakaan dan pemanfaatan TI; dan (d) Ancaman perpustakaan terdiri dari bidang usaha sejenis.

3. Strategi yang digunakan dalam peningkatan manfaat Perpustakaan Daerah Kabupaten Bantul adalah: (a) Meningkatkan kualitas SDM perpustakaan; (b) Meningkatkan jumlah koleksi sesuai minat dan kebutuhan pengguna; (c) Membangun kondisi perpustakaan yang nyaman; (d) Memberikan layanan yang maksimal kepada masyarakat; (e) Membangun kemitraan untuk mengatasi kekurangan sarana dan prasarana serta anggaran dari pemerintah daerah; (f) Meningkatkan pemahaman masyarakat tentang keberadaan dan manfaat perpustakaan melalui kegiatan promosi secara rutin.

Berdasarkan hasil penelitian, pembahasan dan kesimpulan yang diambil, maka disarankan sebagai berikut :

1. Letak koleksi anak sebaiknya di lantai 1 (satu) untuk mencegah terjadinya kecelakaan anak akibat terjatuh di tangga.

2. Mengusulkan dan melobi Badan Kepegawaian Daerah (BKD) untuk menambah jumlah pustakawan atau mengirim pegawai perpustakaan lulusan SMA atau sederajat untuk melanjutkan pendidikan formal kepustakawanan.

3. Menyediakan anggaran khusus untuk kegiatan layanan perpustakaan sore hari dan layanan hari Minggu.

4. Perpustakaan Daerah Kabupaten Bantul memiliki lebih dari 675 perpustakaan binaan. Hal ini memberi peluang bagi peneliti selanjutnya untuk meneliti tentang perpustakaan binaan tersebut.

\section{DAFTAR PUSTAKA}

Bryson, John M. 1999. Perencanaan Strategis: Bagi Organisasi Sosial. Yogyakarta : Pustaka Pelajar.

Rahayuningsih, F [et. al]. 2007. Pengelolaan Perpustakaan. Yogyakarta : Graha Ilmu

Salusu. 1996. Pengambilan Keputusan Stratejik: Untuk Organisasi Publik dan Organisasi Non Profit. Jakarta : Gramedia Widiasarana Indonesia

Rohmiyati, Yuli. 2006. Pemanfatan Perpustakaan Daerah oleh Masyarakat di Badan Pusat Perpustakaan Daerah Yogyakarta(Tesis). Yogyakarta: UGM.

Sulistyo-Basuki. 1994. Periodisasi Perpustakaan Indonesia. Bandung: Remaja Rosda Karya.

Supriyanto, Wahyu. 2005. Strategi Pengelolaan Unit Penunjang Universitas Perpustakaan Universitas Gadjah Mada Yogyakarta (Tesis). Yogyakarta: UGM.

Sutarno NS. 2003. Perpustakaan dan Masyarakat. Jakarta: Yayasan Obor Indonesia . 2005. Tanggung jawab Perpustakaan :

Dalam Mengembangkan Masyarakat Informasi. Jakarta : Panta Rei 